\title{
SEARCH FOR NEW WAYS OF ECOLOGICAL CRISES OVERCOMING
}

\author{
M.Basilaia, M.Zharkova \\ Don state technical university. Rostov-on-Don, Russian Federation \\ science-almanac@mail.ru
}

To date, there is an unprecedented global environmental crisis, which literally turns into the general crisis of civilization in the eyes of the present generation, which adversely affects all spheres of life: economic, spiritual, social. The question of how to understand and find real ways to overcome this crisis today becomes extremely topical. The most common for today and often unpredictable are environmental crises and pollution of the anthropogenic environment, which are largely caused by anthropogenic factors, i.e. various factors caused by and conditioned by human activity. In general, the ecological crisis reflects the social cause - the antagonism of society's relations to the country. The ecological crisis is a crisis not only and not so much the interaction of people with nature. It accompanied with the spiritual crisis - a crisis in the formation of their ecological consciousness, interaction with each other. The solution of the ecological problem must begin with the solution of the problem of "common" consciousness, activity, culture in society, the formation of responsibility for the fate of the Earth. Argumentation of the meaning of co-evolution with the biosphere consists in the fact that the man and all living things on the Earth are derivatives of nature, they are inseparable. Thus, the unity and meaning of the harmonic image of ecological existence must penetrate into the consciousness of each person. Only thank to man, the work of mankind and its biosphere function and only in alliance with man, animate nature can rise to a higher level of its organization. Any solution of global planetary issues, especially those related to the vital activity of civilization and the biosphere, must be based on the ideological origin. And only on the basis of the biosphere development logic and society as an integral part of the biosphere and its nature, mankind has the right to assess the current ecological situation and formulate plans for its operation.Overcoming the fundamental difficulties associated with non-trivial solutions to global problems of harmonic co-evolution depends on the cognitive power of science. Contemporary moral imperative and ecological harmony ideology cannot be formed without the appropriate level of society education.

Key words: ecological crisis, coevolution, noospherogenesis, ecological consciousness.

[Басилаиа М.А., Жаркова М.Г.Поиск новых путей преодоления экологического кризиса]

В настоящее время происходит невиданный ранее общепланетарный экологический кризис, превращающийся буквально на глазах нынешнего поколения в общий кризис цивилизации, пагубно изменяющий все сферы жизни: экономическую, духовную, социальную. Вопрос, как понять и найти реальные пути преодоления этого кризиса, сегодня становится чрезвычайно актуальным. Наиболее распространенными на сегодня и часто непредсказуемыми являются экологические кризисыи загрязнения окружающей среды антропогенного характера, которые во многом вызваны антропогенными факторами, т.е.различного рода фракторами, вызванными и обусловленными человеческой деятельностью. В целом в экологическом кризисе отражается социальная причина - антагонизм отношений общества к природе. Экологический кризис - кризис не только и не столько взаимодействия людей с природой. Он дополняется духовным кризисом - кризисом формирования их экологического сознания, взаимодействия друг с другом. Решение экологической проблемы надо начинать с решения проблемы «общего» сознания, деятельности, культуры в обществе, формирования ответственности за судьбу Земли. Аргументация смысла коэволюции с биосферой состоит в том, что человек и все живое на Земле есть производные природы, они неразделимы. Таким образом, единство и смысл гармонического образа экологического существования должны проникнуть в сознание каждого человека. Только благодаря человеку, работе человечества и ее биосферной функции и только в союзе с человеком живая природа может подняться на более высокую ступень своей организации. Любое решение глобальных планетарных вопросов, тем более связанных с жизнедеятельностью цивилизации и биосферы, должно опираться на мировоззренческие начала. И только на основе логики развития биосферы и общества как неотъемлемой части биосферы и ее природы человечество имеет право оценивать современную экологическую ситуацию и формировать планы своего действия.Преодоление принципиальных трудностей, связанных с нетривиальными решениями глобальных 
проблем гармонической коэволюции, зависит от познавательной силы науки. Без соответствующего уровня образованности общества не может сформироваться идеология экологической гармонии и современный нравственный императив.

Ключевые слова: экологический кризис, коэволюция, ноосферогенез, экологическое сознание.

Mariana A. Basilaia - Ph.D., professor. Don state technical university. Rostov-on-Don, Russian Federation. Maria G. Zharkova - candidate of Biology, associate professor. Don state technical university. Rostov-onDon, Russian Federation.

БасилаиаМариана Артемовна - доктор фрилософрских наук, профрессор. Донской государственный технический университет. г. Ростов-на-Дону, Россия.

Жаркова Мария Геннадьевна - кандидат биологических наук, доцент. Донскойгосударственныйтехническийуниверситет. г. Ростов-на-Дону, Россия.

Mankind, from generation to generation, overcomes the most diverse obstacles in the course of its development and progress. Social progress is quite contradictory phenomenon and includes both constructive and, unfortunately, destructive tendencies in its development. Many problems of interconnection inside the system "person-society-nature" became strained in 20 century. Besides, these problems spread and became strained so hard that began to affect the interests of mankind in whole - to threaten the very existence of civilization and even life itself on our planet. Undoubtedly, the solution of these problems requires the worldwide participation. Therefore, the adopted term "global problems of modernity" characterizes the problem field enormous scale of the vital problems of mankind (political, social, economic, ecological, demographic, scientific and technical), generalizes the perspectives and major directions of the development of society and its future.

The complexity of the problems under discussion, concerningthe contemporary world development as a whole is not so much in their multidimensionality,as in the deep perplexity, inextricable interconnectedness and interdependence of these aspects, making their isolated solution to be practically impossible. So, in a complex of ecological problems, natural, social, technological and cultural factors are tied into one tight knot: ensuring the further economic development of mankind with natural resources obviously implies the prevention of increasing pollution of the environment.

The ecological problem and its solution are considered to be in priority among a number of global problems of our time. It arose in connection with the need to overcome the ecological crisis. Ecology studies the relationship between a living organism, or a person with the environment. Considering that already in the XIX century. the society began to be purposefully compared with a living developing organism that requires permanently expanding "living space", the original meaning, included by the father of ecology E. Haeckel began to be important for philosophers. Mainly the environment should be the "home" for a person, where he feels comfortable, cozy, safe.For this, certain mechanisms are needed to harmonize the properties of the organism with the properties of the environment, the search for which has become the basis of a new research work type in the environment as a field of scientific knowledge. At the present time, ecology has acquired among other sciences the status of the leading science of integrative and interdisciplinary nature in view of the exceptional topicality of ecological problems for people's lives and the treatment of its problems by numerous specialists of various profiles.

In the society development process, environmental controversies constantly arise between man and nature, which, in the course of their development, change and become more complicated up to ecological crises. Both heterogeneous sides of the contradiction are highly active, therefore this contradiction cannot be considered either purely social, social, or even natural.Herewith, as it is known, changes in the nature can be not only the 
result of the society activity, as nature also has immanent changes, which are generated by inside processes, independent from the society.

In connection with this, various ecological situations, denoting a discrete and restricted fragment in spatio-temporal framework in the system "society-nature" can be developed.The most common for today and often unpredictable are environmental crises and pollution of the anthropogenic environment, which are largely caused by anthropogenic factors, i.e. various factors caused by and conditioned by human activity. Often, the scientific and technical cause of environmental crises is technologies that are necessary with the current intensity of production. Of course, one technology differs from the other. There are technologies that are environmentally successful, and also technologies that are economically successful, yielding high profits, but environmentally damaging: in pursuit of profit in the course of everyday life and activity, nature savings, renewable and nonrenewable resources very limited in volume are squandered. That is, the origins of the ecological crisis are correlated in the discrepancy between the laws of social and technological development and the laws of evolution of the biosphere.In general, the ecological crisis reflects the social cause - the antagonism of society's relations to the country. For certain economic entities, the issues of careful treatment of nature and its resources do not exist due to the dominance in their minds and activities of the narrow-utilitarian, mercantile-bureaucratic approach.

But production technologies are used by people. And since the production is a collective labor, the ecological relations acquire the character of socially-ecological relations. Two important factors must be taken into account: 1) ecological activities include the cooperation of many society members, states, and today this cooperation must be carried out on a global scale. The attitude of people to each other, in one way or another, is related to nature, so socially-environmental relations among people are interrelated and dependent on their relationship to nature; 2) ecological activity is not isolated, but occurs in the total mass of a multifaceted human activity in the transformation of the social environment[1]. People's consciousness plays the leading role in the socially-economical activity, so in any other. After all, the people who use certain technologies know everything about these technologies, they know their characteristics by the ecological criterion. Hence the ecological crisis as a result of a consciously aggressive activity in relation to the environment is a crisis not only and not so much the interaction of people with nature. It is supplemented by a spiritual crisis - a crisis in the formation of their ecological consciousness, interaction with each other. At all phases of the history of human society, these two aspects of activity are interrelated. Therefore, socio-ecological relations - the essence, the ecological aspect of the whole system of social relations, both material, including economic, and ideological, including politics, moral issues, law and morality.

At present, there is an unprecedented global environmental crisis, which literally turns into the general crisis of civilization in the eyes of the present generation, which adversely affects all spheres of life: economic, spiritual, social. Awareness of such a wild situation causes a crisis in the minds of sufficiently educated people, and scientists are concerned about the development of new theories and concepts of solving environmental problems and emerging from an environmental crisis. The question about understanding and finding the real ways of this crisis overcoming becomes extremely urgent today.

The ecological crisis is thought by many as something external to the person. The way out of the ecological crisis is still seen through the solution of technocratic, at times, particular tasks: creation of so-called environmentally friendly production facilities, versatile monitoring - control over the technical equipment and technologies introduced in the industry and all that. The solution of the ecological problem must begin with the solution of the problem of "common" consciousness, activity, culture in society, the formation of responsibility for the fate of the Earth. Argumentation of the meaning of co-evolution with the bios- 
phere consists in the fact that man and all living things on the Earth are derivatives of nature, they are inseparable. And there "as we sow, so we reap", there is no another way in other civilization development. Thus, the unity and meaning of the harmonious image of ecological existence must penetrate into the consciousness of each person. Strange as it may seem, but the animal world and the whole flora of the Earth "realized" initially and "instinctively"'adhere" to all the canons of harmonic unity with nature. For thousands of years, the truth is known to mankind: how a man relates to nature, so nature refers to man. But the question is: To what extent did this knowledge penetrate into consciousness? After all, world history shows that none of the existing civilizations could not avoid environmental stresses and disasters.

Today, the dominant function of public administration in all countries is to predict and ensure the safety of society from such disasters.Environmental crises, in essence, are determined by the depletion of human ecological niches. Such crises occupy a special place in the life of society, introducing dangerous destabilization in it, although this occurs at relatively short intervals.But history knows also crises of a different kind - catastrophes of a global scale, the result of which were complex restructuring in the life of civilizations.

The question arises: what is the root of the problem? Mankind realizes that coevolution with the biosphere, the harmonious development of society and nature is the only thing to which there is no alternative in the further existence of civilization. In real life we see that unity with nature, its co-evolution with man, the desire for pure thoughts of the noosphere can only be good as ideas. But the ways to implement these ideas in today's realities of the modern state reduce the profitability of the economy so much that such unification is impossible. It is unobtainable without fabulously expensive state programs. Nothing can be opposed to a better way of life than the purity of water, air and sky. This suggests that it is extremely important to form and consolidate in our minds the image of ecological culture, the need for action towards harmony with the surrounding nature. The main aim is to preserve the parameters of the biosphere within the framework necessary for sustainable development of society. The man has always changed the conditions of his habitation, influencing the properties of nature. But nowadays it happens during the lifetime of one generation, which drastically changes the ecological picture associated with any unpredictable dangers. The mind in the conditions of an imminent ecological catastrophe must give the person a certain field of foresight. It must create certain conditions and opportunities for co-evolution or new anthropocentrism, presupposing a purposeful impact on the evolution of the biosphere.

Technique, especially electronic, robotics, mechatronics, computer complexes are stepping on us in a stately step. All this provides employment, followed by money. Some of the philosophers said that "a person - the meanings with which it is filled", but with what is it filled? The mass media are overwhelmed with ideas, thoughts, methods and intricacies of various forms of violence. The epicenter of such information pollution, which is corrupting people's consciousness, is moving from the West (the cradle of all these "technologies") to the East. Scenarios, overcrowded with meanings of evil, disfigure personality, the destruction of personality leads to the destruction of society. The ancients brought up their people by the example of heroes. Violence prevails in Western films and arts, but it is an infection from which there are no "pharmaceutical" remedies.

Today, when a person has to (for the sake of all alive on the planet) subordinate his actions, lifestyle, his social organization to modern realities when the future of mankind depends on a deeply rational, harmonious dialogue between man and nature - a positive change in the structure of thinking, the evolution of consciousness occupy the dominant place in the formation of noospherogenesis. The problems of the ecological consciousness formation and issues of man self-improvement are at the junction of a number of sciences: ecology, philosophy, psychology, ethics, pedagogy, etc. In connection with the importance 
of the social role and even the historical mission of ecological consciousness in the development and existence of the entire civilization, scientists began to talk about the formation of even a common planetary ecological awareness, the bearer of which will be humanity as a universal cognitive and active subject.

In modern science, the processesof integrating knowledge dominate, but they are manifested in a special form, being conditioned to the specificity of existing historical realities. Integration processes are in demand in two cases: 1) they can take place within the already established system of ecological knowledge - in this case they lead to increase in the level of its integrity and organization; 2) within the framework of entirely new synthetic scientific branches formation there is the integration of scientific knowledge on the basis of close interaction and intertwining of scientific disciplines to solve problems of planetary nature. Thus, the formation of the global ecology - a theoretical, concrete scientific basis for environmental safety - as a new industry is connected with the research subject definition, the development of concepts corresponding to this subject, the discovery of a fundamental law that corresponds to the subject, the development of principles, theories that explain many facts within the global ecology. One speaks about new knowledge fixation in new more generalized concepts, categories, theories, laws.

According to V.I. Vernadsky, a person "...can and should with his work and cardinally reconstruct the sphere of his life, in comparison with what was earlier" [3].Only thanks to a man, the work of mankind and its biosphere function and only in alliance with man, living nature can rise to a higher level of its organization. The transition to a period of controlled socio-natural evolution will enable human society to rise to the level of noogenesis. This means that each person will have the opportunity, to the best of his ability, to take part in the process of preserving, ennobling and improving nature. In the process of co-evolution of Man and Nature, the leading role belongs to man. In order to reach a new stage of maturity, which deserves to be called noogenesis, a person must participate in the evolution of living nature. This condition, under which Nature, permeated by the human Mind, becomes spiritualized.Thus, although technical development is absolutely necessary, but it is not enough. Civilization must become different, and the spiritual world of man must change. Therefore, it is necessary to search for the solution of problems in the person himself, in changing his personality, which will be promoted by the formation of a new ecological consciousness.

The energetic efforts on development and realization of "100-year plan"the aim of which - rescue of global environment began to be widely spread in the beginning of 90-s in Japan. The strategy of this work is based on the opportunities created in this country, which simultaneously ensure the preservation of the natural environment and significantly improve the quality of products, increase labor productivity and economic efficiency. Unfortunately, many countries, including Russia, do not have such program. In order to create similar programs, priority in socio-economic development should be given to science and education, which are directly related to human cognitive activity.

In our opinion, any solution to global planetary issues, all the more related to the life activity of civilization and the biosphere, must be based on worldview principles. And only on the basis of the logic of development of the biosphere and society as an integral part of the biosphere and its nature, mankind has the right to assess the current ecological situation and formulate plans for its operation [2]. The ideological foundations, ultimately, should determine the idea and meaning of the human society action, although the process of the world outlook forming (and the formation of the corresponding consciousness) is extremely complex and subject to many factors of the social plane, such as lifestyle and customs, relationships with different people, the nature of ecosystems. In the search for new solutions to the development of the sphere of reason and the harmonic interactions of nature and society, the cognitive power of science plays a crucial role at the present 
time.Scientifically, we cannot manage nature and its formidable spontaneous manifestations today. Any artificial interference of modern society in natural global ecosystems easily becomes destructive with catastrophic consequences. It is important to realize that overcoming the fundamental difficulties associated with non-trivial solutions to the global problems of harmonic co-evolution depends on the cognitive power of science. Without the appropriate education level of society, the ideology of ecological harmony and the contemporary moral imperative can not be formed.

\section{Лumepamypa}

1. Аствацатуров А.Е., Басилача М.А., Терещенко Н.В. Экологическое образование и инженерная подготовка в США и России // Экология, безопасность и эффрективность производства. Ростов-на-Дону, 1998.

2. Басилача М.А. Синергетическая парадигма становления ноосферогенеза в условиях глобального экологического кризиса. Ростов-на-Дону, 2010.

3. Вернадский В.И. Химическое строение биосфреры Земли и ее окружения. М., 1965.

\section{References}

1. Astvatsaturov A.E., Basilaia M.A., Tereshchenko N.V.Ecological education and engineering trainingin the USA and RussiauРоссии // Ecology, safety and efficiency of production. Rostov-on-Don, 1998.

2. Basilaia M.A.Synergetic paradigm of the noospheregenesis formation in the conditions of the global ecological crisis. Rostov-on-Don, 2010.

3. Vernadsky V.I. The chemical structure of the Earth biosphere and its environment. Moscow, 1965. 